\title{
Polyunsaturated fatty acids modulate prostaglandin synthesis by ovine amnion cells in vitro
}

\author{
S E Kirkup, Z Cheng, M Elmes, D C Wathes and D R E Abayasekara \\ Endocrinology, Development, Genomics and Reproduction Group, Department of Veterinary Basic Sciences, \\ Royal Veterinary College, Hawkshead Lane, North Mymms, Hatfield, Hertfordshire AL9 7TA, UK
}

Correspondence should be addressed to D R E Abayasekara at Department of Veterinary Basic Sciences, Royal Veterinary College, Royal College Street, London NW1 OTU, UK; Email: rabayase@rvc.ac.uk

\begin{abstract}
Diets or supplements high in n-3 and n-6 polyunsaturated fatty acids (PUFAs) have been shown to influence the timing of parturition. PUFAs are substrates for prostaglandin (PG) synthesis, and PGs play central roles in parturition. Hence, the effects of altering PUFA composition may be mediated through alterations in the type and relative quantities of PGs synthesised. Therefore, we have investigated the effects of a range of $n-3$ and n-6 PUFAs in vitro on PG synthesis by amnion cells of late gestation ewes. The $n-6$ PUFA, arachidonic acid (20:4, n-6), increased synthesis of two-series PGs. Degree of stimulation induced by the n-6 PUFAs was dependent on the position of the PUFA in the PG synthetic pathway, i.e. PG production of the two-series (principally prostaglandin $\mathrm{E}_{2}: \mathrm{PGE}_{2}$ ) increased progressively with longer chain PUFAs. Effects of $\mathbf{n}-3$ PUFAs on output of PGE $_{2}$ were more modest and variable. The two shorter chain $\mathbf{n}-3$ PUFAs, $\alpha$-linolenic acid (18:3, $n$-3) and stearidonic acid (18:4, n-3), induced a small but significant increase in PGE $_{2}$ output, while the longest chain n-3 PUFA docosahexaenoic acid (22:6, n-3) inhibited PGE $_{2}$ synthesis. Dihomo- $\gamma$-linolenic acid (20:3, n-6), the PUFA substrate for synthesis of one-series $P G s$, induced an increase in $\mathrm{PGE}_{1}$ generation and a decrease in $\mathrm{PGE}_{2}$ and $\mathrm{PGE}_{3}$ outputs. Hence, we have demonstrated that PUFA supplementation of ovine amnion cells in vitro affects the type and quantity of PGs synthesised.

Reproduction (2010) 140 943-951
\end{abstract}

\section{Introduction}

The saturated fat content of the human diet has been implicated as a major risk factor in cardiovascular disease, so the Department of Health (DoH) recommends that UK consumers reduce saturated fat intake in favour of unsaturated fats (DoH 1994). Although diets high in polyunsaturated fatty acids (PUFAs) are purportedly healthier, quantities of PUFAs consumed are generally far in excess of those needed for normal physiological functioning. This is particularly so with regard to the many supplements rich in PUFAs, which are utilised by women of reproductive age to alleviate symptoms of premenstrual syndrome (Bendich 2000) and rheumatoid arthritis (Remans et al. 2004, Goldberg \& Katz 2007).

PUFAs are grouped into families according to the position of the first double bond along the hydrocarbon chain, and are hence known as n- 6 and n-3 PUFAs. Both n-6 and n-3 PUFAs are precursors for a range of signalling molecules including prostaglandins (PGs; Smith 1989, 1992, Lands 1992, Smith et al. 2000, Tapiero et al. 2002). Arachidonic acid (AA, 20:4, n-6) is the immediate precursor for the two-series PGs, while the three-series PGs are derived from eicosapentaenoic acid (EPA, 20:5, n-3) and the one-series PGs originate from dihomo- $\gamma$-linolenic acid (DGLA, 20:3, n-6) (Lands 1992). The amounts and relative proportions of $n-6$ and n-3 PUFAs in the diet may thus alter both the amount and type of PGs synthesised.

PGs influence many key processes in reproduction including ovulation (Carvalho et al. 1989), luteolysis (McCracken et al. 1970, Auletta \& Flint 1988) and parturition (Thorburn 1991, Whittle et al. 2000, Challis et al. 2002, Mitchell \& Taggart 2009) in numerous species (Weems et al. 2006, Jabbour et al. 2009). It is generally accepted that the onset of labour in most mammalian species including sheep is associated with an increase in n-6-derived two-series PGs (Challis et al. 2000, Olson 2003, Myatt \& Sun 2010) produced by the intrauterine tissues (placenta, amnion, chorion, decidua/ endometrium and myometrium) (sheep: Rice et al. 1990, 1995, Thorburn 1991, McLaren et al. 1996, 2000; guinea pig: Welsh et al. 2005; human: Slater et al. 1999, Sawdy et al. 2000). Rats, humans and sheep fed a high n-6 PUFA diet have been shown to have shortened pregnancies (Olsen \& Secher 1990, Olsen et al. 1991, Elmes et al. 2005), while animals (e.g. sheep) and humans (e.g. Faroese women and Greenland Eskimos) consuming diets rich in $n-3$ PUFAs showed delayed 
onset of uterine contractions at parturition and hence longer gestation periods (Horrobin \& Manku 1990, Olsen et al. 1991, Baguma-Nibasheka et al. 1999, Szajewska et al. 2006). More recent studies in humans have also tended to support a role for dietary n-3 PUFAs in the timing of parturition with a diet devoid of fish during pregnancy being associated with a higher risk of pre-term delivery (Olsen et al. 2006), while a diet that included a modest intake of fish during gestation seemed to decrease the risk of spontaneous pre-term delivery (Olsen et al. 2007). A possible explanation for the fish diet-induced delayed onset of parturition could be that the three-series PGs generated from n-3 PUFA substrates have less biological potency than their two-series counterparts generated from n-6 PUFA substrates. However, it is important to recognise that this is not a universal phenomenon as anti-aggregatory studies in rabbit platelets have shown that two-series PGs are less potent than their one- and three-series counterparts (Kobzar et al. 1993).

PGs regardless of series exert their actions via common receptors, i.e. $\mathrm{PGE}_{1}, \mathrm{PGE}_{2}$ and $\mathrm{PGE}_{3}$ exert their actions via the various PGE receptors, EPs 1-4 (Coleman et al. 1994, Sugimoto \& Narumiya 2007, Furuyashiki \& Narumiya 2009). A possible explanation for the differences in potency of action of different series $P G$ s could lie in their relative affinities for their respective $P G$ receptors. A report that $\mathrm{PGE}_{2}$ has greater affinity for EP receptors when compared to $\mathrm{PGE}_{3}$ in human embryonic kidney 293 cells tends to support this contention (Wada et al. 2007). On the other hand, thromboxanes $A_{2}\left(T X A_{2}\right)$ and $A_{3}\left(T X A_{3}\right)$ were reported to be equipotent in inducing aggregation despite $T X A_{2}$ exhibiting a greater affinity for the cognate receptor when compared to $\mathrm{TXA}_{3}$ (Wada et al. 2007). These results illustrate how difficult it is to extrapolate and hence predict relative effects of the different series PGs in different biological situations.

Apart from acting as substrates for PG endoperoxide synthase (PTGS) enzymes (Lands 1992, Smith 1992), PUFAs also affect the expression (in bovine/ovine uterus: n-6 PUFA: Sheldrick et al. 2007; n-3 PUFA: Ma et al. 2000) and activities of these enzymes (Smith 2005). The increasing production of PGs by the feto-placental tissues during the 15-20 days prior to parturition is key to the successful initiation and progression of labour in the ewe (Olson et al. 1985, Thorburn 1991, Gyomorey et al. 2000). The increased production of PGs in intrauterine tissues towards the end of gestation could (at least in part) be due to increased expression/activity of PTGS1 and PTGS2 (McLaren et al. 2000, Whittle et al. 2000).

PG synthesis in the ovine amnion at term would appear to depend mainly on PTGS1 as it was found to be highly expressed in amniotic tissue from ewes in spontaneous labour, whereas PTGS2 was not detected (McLaren et al. 1996, 2000). In ovine foetal membranes, levels of PTGS1 were highest within the amnion (e.g. 25-fold higher than in the chorion) (McLaren et al. 2000). PTGS1 was also found to be highly expressed within the guinea pig amnion, and its preferential inhibition was associated with prolonged gestation (Welsh et al. 2005). PUFAs, derived from the diet and released from storage in the phospholipid component of cell membranes by the actions of phospholipase $\mathrm{A}_{2}\left(\mathrm{PLA}_{2}\right)$, are implicated as a major source of substrate for PTGS enzymes. This is substantiated by studies in the human, which show a striking loss of AA, 20:4, n-6 from phosphatidylethanolamine and phosphatidylinositol of amnion during early labour (Okita et al. 1982) and an increase in specific activity of PTGS in the amnion after spontaneous onset of labour (Okazaki et al. 1981). This is associated with increased metabolism of AA, 20:4, n-6 via PTGS to two-series PGs by amnion cells (Bennet et al. 1993). The observation that the ovine amnion contained greater $\mathrm{PLA}_{2}$ activity than either the myometrium or the placenta (Grieves \& Liggins 1976) and that induction of labour with corticotrophin induced a marked increase in amniotic $\mathrm{PLA}_{2}$ activity (Grieves \& Liggins 1976) provides further evidence to support a role for $\mathrm{PLA}_{2}$-derived $\mathrm{AA}$, 20:4, n-6 metabolism to two-series PGs in inducing ovine parturition. Of the many different isoforms of $\mathrm{PLA}_{2}$, a $85 \mathrm{kDa}$ cytosolic $\mathrm{PLA}_{2}\left(\mathrm{CPLA}_{2}\right)$ has been localised within the human amnion (Myatt \& Sun 2010), and its pivotal role in parturition has been amply demonstrated by the fact that $\mathrm{CPLA}_{2}$ null mice were unable to deliver offspring (Uozumi et al. 1997).

From the preceding, it is clear that PG generation by the amnion has an effect on parturition in the ewe. However, there is a paucity of information as to how PUFAs either in vivo or in vitro influence PG output from the amnion. Hence, we have addressed this deficit by investigating the effects of $n-6$ or n-3 PUFAs in vitro on PG synthesis by amnion cells derived from late gestation ewes. Owing to the possible complex interactions between PUFAs, we have restricted the scope of the present study to only explore the effects of individual PUFAs in vitro on PG generation by ovine amniotic cells.

\section{Results \\ PG production}

In this study, effects of PUFA supplementation on PG synthesis in the ovine amnion were evaluated by measuring changes in $\mathrm{PGE}_{2}$ in cell culture medium. $\mathrm{PGE}_{2}$ was chosen as a representative parameter for perturbations of PG synthesis in the amnion, as preliminary analysis showed the amount of $\mathrm{PGE}_{2}$ synthesised to be considerably greater than of $\mathrm{PGF}_{2 \alpha}$ during the same $24 \mathrm{~h}$ incubation period $\left(\mathrm{PGE}_{2}, 0.93 \pm 0.06 \mathrm{ng} / \mathrm{ml}\right.$ per 250000 cells per $24 \mathrm{~h} ; \mathrm{PGF}_{2 \alpha}, 0.083 \pm 0.004 \mathrm{ng} / \mathrm{ml}$ per 250000 cells per $24 \mathrm{~h}$; ratio 11.2:1). These results were derived from multiple incubations (24 wells) of amnion cells derived from three sheep. 


\section{Effects of n-6 PUFA supplementation in vitro on $P G$ production}

The dose-response to AA, 20:4, n-6 was investigated over a comprehensive range of concentrations $(0.1-1000 \mu \mathrm{M}$; Fig. 1). $\mathrm{PGE}_{2}$ synthesis reached maximum levels at a dose of $100 \mu \mathrm{M} \mathrm{AA}, 20: 4, \mathrm{n}-6\left(184 \mathrm{ng} / \mathrm{ml} \pm 22.6 \mathrm{PGE}_{2}\right.$ over $45 \mathrm{~h}$ of culture). Above this concentration, $\mathrm{PGE}_{2}$ synthesis declined, and the viability of the cells was compromised. Hence, a concentration of $100 \mu \mathrm{M}$ PUFA was used for all subsequent experiments. Concentrations of up to and including $100 \mu \mathrm{M}$ PUFA (either $\mathrm{n}-6$ or $\mathrm{n}-3$ ) had no effect on cell viability compared to untreated control cells.

Figure 2 shows that, when supplemented with a variety of $\mathrm{n}-6$ PUFAs $(100 \mu \mathrm{M})$ for $45 \mathrm{~h}$, ovine amnion cells cultured in vitro increased production of two-series PGs compared to untreated control cells. Enhancement of PG synthesis varied considerably with each different n-6 PUFA supplemented: control $\sim$ linolenic acid (LA, 18:2, n-6) $<\gamma$-linolenic acid (GLA, 18:3, n-6) $<$ DGLA, $20: 3, \mathrm{n}-6<\mathrm{AA}, 20: 4, \mathrm{n}-6$. Cells treated with $20 \mu \mathrm{M}$ PUFAs responded in a similar manner to those treated with $100 \mu \mathrm{M}$ PUFAs, but the magnitude of response was smaller (data not shown).

\section{Responses to in vitro supplementation with n-3 PUFAs}

When cells were supplemented with PUFAs of the n-3 family, they did not respond in the same manner as the corresponding members of the n-6 PUFA family with respect to PG synthesis (Fig. 3). Shorter chain PUFAs $\alpha$-linolenic acid (ALNA), 18:3, n-3 and stearidonic acid (SA), 18:4, n-3 were stimulatory, while EPA, 20:5, n-3 was without significant effect and the longer chain PUFA docosahexaenoic acid (DHA), 22:6, n-3 was inhibitory. Compared with responses to different members of the n-6 family, the absolute differences in $\mathrm{PGE}_{2}$ synthesis were, however, small (note the differences in scale between Figs 2 and 3 ).

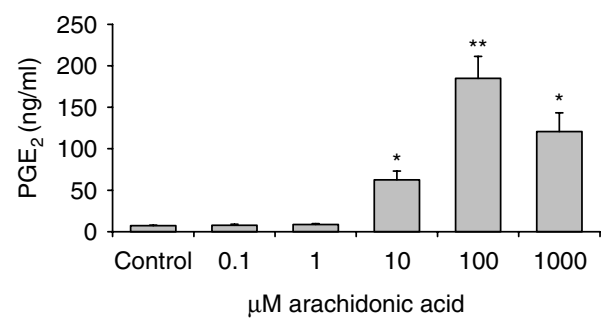

Figure 1 Effect of arachidonic acid (AA, 20:4, n-6; 0-1000 $\mu \mathrm{M})$ on $\mathrm{PGE}_{2}$ synthesis by ovine amnion cells over $45 \mathrm{~h}$ of culture. In vitro treatments were replicated in four wells of cells in each experiment. Each experiment was repeated with cells from three different sheep. Cell culture medium was supplemented with treatments: $0,0.1,1.0$, 10,100 or $1000 \mu \mathrm{M}$ PUFA. Prostaglandin synthesis is expressed as mean \pm s.E.M. (ng/ml PGE 2 per 45 h). $P$ values represent significant difference from control cells; ${ }^{*} P<0.01,{ }^{* *} P<0.001$.

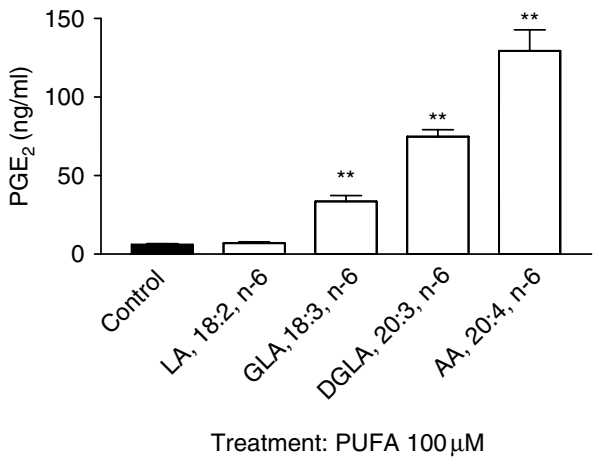

Figure 2 Effects of n-6 PUFAs $(100 \mu \mathrm{M})$ (linoleic acid (LA, 18:2, n-6), $\gamma$-linoleic acid (GLA, 18:3, n-6), dihomo- $\gamma$-linoleic acid (DGLA, 20:3, $\mathrm{n}-6)$ and arachidonic acid (AA, 20:4, n-6)) in vitro on $\mathrm{PGE}_{2}$ synthesis by ovine amnion cells over $45 \mathrm{~h}$ of culture. In vitro treatments were replicated in four wells of cells in each experiment. Each experiment was repeated in cells from three different sheep. Cell culture medium was supplemented with treatments: 0 (control) or $100 \mu \mathrm{M}$ PUFA. Prostaglandin synthesis is expressed as mean \pm s.E.M. $\left(\mathrm{ng} / \mathrm{ml} \mathrm{PGE}{ }_{2}\right.$ per $45 \mathrm{~h}$ ). $P$ values represent significant difference from control cells; ${ }^{* *} P<0.001$

\section{Detection of different isoforms of PGE in culture medium using specific enzyme immunoassay and HPLC}

Detection of $P G E_{1}$ by enzyme immunoassay

Figure 4 shows that ovine amnion cells when supplemented with a variety of $n-6$ PUFAs $(100 \mu \mathrm{M})$ for $45 \mathrm{~h}$ in vitro increased production of one-series PGs compared to untreated control cells. Enhancement of $\mathrm{PGE}_{1}$ synthesis varied considerably with each different $n-6$ PUFA supplemented: control $\sim$ LA, 18:2, n- $6<$ GLA, 18:3, n-6< DGLA, 20:3, n-6>AA, 20:4, n-6.

\section{Detection of alternative isoforms of PGE after separation by HPLC}

Three different isoforms of PGE in samples of cell culture medium were measured by RIA following separation of the different isoforms by HPLC.

Results from analysis of cell culture medium by HPLC demonstrate the presence of almost equal quantities of all three PG isoforms in culture medium from control cells. Cells supplemented with $100 \mu \mathrm{M}$ AA, 20:4, n-6 produced predominantly two-series PGs, while those supplemented with $100 \mu \mathrm{M}$ DGLA, 20:3, n-6 produced predominantly one-series $\mathrm{PGs}$ and those supplemented with $100 \mu \mathrm{M}$ EPA, 20:5, n-3 produced significantly greater quantities of three-series PGs as shown in Table 1.

\section{Discussion}

The ovine amnion is an important site for PG synthesis in both pre-term and term labour (Olson et al. 1986, McLaren et al. 1996, 2000, Palliser et al. 2006). Hence, the present study was designed to investigate whether 


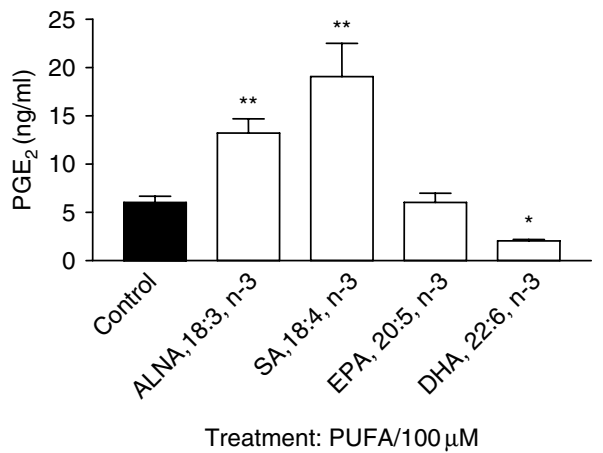

Figure 3 Effects of $n-3$ PUFAs $(100 \mu \mathrm{M})(\alpha$-linolenic acid (ALNA, 18:3, n-3), stearidonic acid (SA, 18:4, n-3), eicosapentaenoic acid (EPA, 20:5, $\mathrm{n}-3)$ and docosahexaenoic acid (DHA, 22:6, n-3)) in vitro on $\mathrm{PGE}_{2}$ synthesis by ovine amnion cells over $45 \mathrm{~h}$ of culture. In vitro treatments were replicated in four wells of cells in each experiment. Each experiment was repeated with cells from at least three different sheep. Cell culture medium (DMEM/F-12 with $0.1125 \%$ fatty acid-free BSA and $0.1 \mathrm{ml} / 100 \mathrm{ml} \mathrm{ITS}$ ) was supplemented with treatments: control or $100 \mu \mathrm{M}$ PUFA. Prostaglandin synthesis is expressed as mean \pm S.E.M. $(\mathrm{ng} / \mathrm{ml} \mathrm{PGE} 2$ per $45 \mathrm{~h})$. $P$ values represent significant difference from control cells; ${ }^{*} P<0.05,{ }^{* *} P<0.001$.

PUFAs in vitro could affect PG synthesis by isolated ovine amnion cells in primary culture. Many previous studies have involved the use of an immortalised amnion cell line (WISH cells - reviewed in Pavan et al. (2003)), but there is a paucity of data derived from experiments using primary cultures of amnion cells. $\mathrm{PGE}_{2}$ was chosen as a representative parameter for perturbations of PG synthesis in the amnion, as preliminary analyses showed $\mathrm{PGE}_{2}: \mathrm{PGF}_{2 \alpha}$ synthesis to be $>10: 1$. Okazaki et al. (1981) similarly reported that the ratio of $\mathrm{PGE}_{2}: \mathrm{PGF}_{2 \alpha}$ in human amnion tissues after spontaneous labour and at caesarean section before the onset of labour was in the region of 30:1. We show here that the addition of different PUFAs in vitro had major effects on the levels of $\mathrm{PGE}_{2}$ production in vitro. These results suggest that PUFAs (dietary and supplements) could potentially alter the timing of parturition through changes in PG synthesis.

The present study demonstrated that, when supplemented with selected n-6 PUFAs for $45 \mathrm{~h}$, amnion cells from late gestation ewes, cultured in vitro, increased synthesis of two-series PGs compared to untreated control cells. All the n-6 PUFAs, except LA, 18:2, n-6, increased $\mathrm{PGE}_{2}$ synthesis. Significantly, the position of the supplemented PUFA in the PG synthetic pathway governed the extent to which $\mathrm{PGE}_{2}$ synthesis was enhanced (Fig. 2), with $\mathrm{PGE}_{2}$ production increasing progressively with the more elongated PUFAs. In agreement with the present studies, Arntzen et al. (1998) obtained similar responses in human decidual cell cultures supplemented with $50 \mu \mathrm{M}$ n-6 PUFAs, i.e. $L A, 18: 2, n-6$ had no significant effect on $P E_{2}$ synthesis, whereas all other n-6 PUFAs stimulated $\mathrm{PGE}_{2}$ (and $\mathrm{PGF}_{2 \alpha}$ ) synthesis in the order: GLA, 18:3, n-6 $<$ DGLA, 20:3, n-6 < AA, 20:4, n-6.

It is clear that elongation and desaturation of n-6 PUFAs to AA, 20:4, n-6 will be rate limited by the presence/absence of relevant enzymes $(\Delta-5$ desaturase, elongase and $\Delta-6$ desaturase) within the ovine amnion. Thus, supplementation with LA, 18:2, n-6 or GLA, 18:3, n-6 may lead to a build-up of DGLA, 20:3, n-6. As DGLA, 20:3, n- 6 is the precursor for the one-series PGs (as well as being an intermediate in the two-series synthetic pathway), this could potentially lead to an increase in the production of one-series PGs (Belch \& Hill 2000). Alternatively, DGLA, 20:3, n- 6 may itself be metabolised to various hydroxy derivatives, which could feed back and inhibit the desaturation and elongation enzymes in the synthetic pathway. Although there is little information regarding the expression of these enzymes in ovine amnion tissue, our results suggest that they are likely to be present and active, as we observed an increase in PGE $\left(\mathrm{PGE}_{1}\right.$ and $\mathrm{PGE}_{2}$, Figs 2 and 4) synthesis following supplementation with GLA, 18:3, n-6 and DGLA, 20:3, n-6. This notion is indirectly supported by the observed increase in $\Delta-6$ desaturase activity in the ovine placenta during the latter stages of gestation (Shand \& Noble 1981).

When effects of $n-3$ PUFAs on two-series PG synthesis were compared to effects of equivalent n-6 PUFAs, there were very clear differences in responses of amnion cells. There was a small increase in synthesis of $\mathrm{PGE}_{2}$ with the two shorter chain n-3 PUFAs ALNA, 18:3, n-3 and SA, $18: 4, \mathrm{n}-3$, and a decrease in $\mathrm{PGE}_{2}$ synthesis by the longest chain n-3 PUFA DHA, 22:6, n-3 (Fig. 3). EPA, $20: 5, n-3$ on the other hand had no effect on $\mathrm{PGE}_{2}$

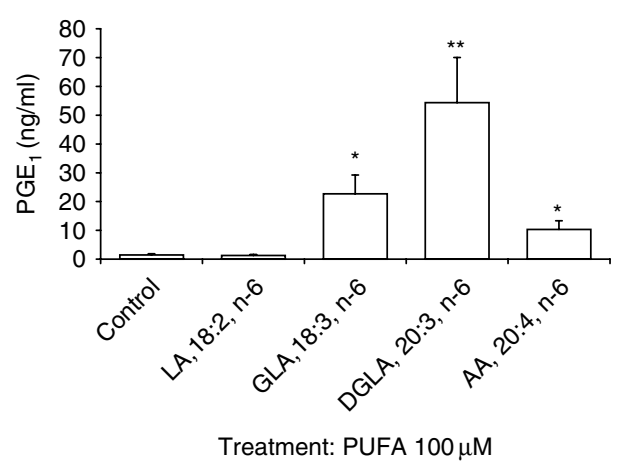

Figure 4 Effects of $n-6$ polyunsaturated fatty acids (PUFAs) in vitro on synthesis of prostaglandin $\mathrm{E}_{1}\left(\mathrm{PGE}_{1}\right)$ by ovine amnion cells. Cells cultured from sheep on control diet. Cell culture medium (DMEM/F-12 with $0.1125 \%$ fatty acid free BSA and $0.1 \mathrm{ml} / 100 \mathrm{ml}$ ITS media supplement) was supplemented with treatments: 0 (control) or $100 \mu \mathrm{M}$ PUFA (PUFAs used are linoleic acid (LA, 18:2, n-6), $\gamma$-linolenic acid (GLA, 18:3, n-6), dihomo- $\gamma$-linolenic acid (DGLA, 20:3, n-6) or arachidonic acid (AA, 20:4, n-6)). In vitro treatments were replicated in four wells of cells in each experiment. Each experiment was repeated at least three times with cells isolated from different sheep. $\mathrm{PGE}_{1}$ synthesis is expressed as mean \pm s.E.M. (ng $P \mathrm{PE}_{1} / \mathrm{ml}$ per $45 \mathrm{~h}$ ). $P$ values represent significant difference from control cells; $* P<0.05,{ }^{* *} P<0.001$. 
Table 1 Effects of n- 6 and $n-3$ polyunsaturated fatty acids (PUFAs) in vitro on synthesis of different isoforms of prostaglandin $E$ (PGE) in ovine amnion cells. Cell culture medium (DMEM/F-12 with $0.1125 \%$ fatty acid-free BSA and $0.1 \mathrm{ml} / 100 \mathrm{ml}$ ITS media supplement) was supplemented with treatments: 0 (CONT) or $100 \mu \mathrm{M}$ PUFA (dihomo- $\gamma$ linolenic acid (DGLA, 20:3, n-6), arachidonic acid (AA, 20:4, n-6) or eicosapentaenoic acid (EPA, 20:5, n-3)) for 45 h. Results show PGE measured by RIA after concentration of individual peaks separated by HPLC. In vitro treatments were replicated in four wells of cells in each experiment. Each experiment was repeated three times with cells isolated from an individual sheep on each occasion. PG synthesis is expressed as (mean) percentage PGE/45 h. For HPLC separation, the incubation medium from all four wells that received the same treatment was pooled. Separated fractions containing different isoforms were freeze-dried before being subjected to RIA for PGE. This yielded a single value for each PGE isoform for each experimental animal.

\begin{tabular}{lcccc}
\hline & \multicolumn{3}{c}{$\begin{array}{c}\text { Mean percentage of each isoform } \\
\text { of PGE in samples }\end{array}$} & \\
\cline { 2 - 4 } & & & & \\
PUFAs & $\mathrm{PGE}_{1}$ & $\mathrm{PGE}_{2}$ & $\mathrm{PGE}_{3}$ & $\begin{array}{c}\text { Total } \mathrm{ng} P G E / \mathrm{ml} \\
\text { per } 45 \mathrm{~h}\end{array}$ \\
\hline CONT & $36.0 \pm 5.0$ & $30.7 \pm 7.5$ & $33.0 \pm 7.4$ & $31.8 \pm 10.1$ \\
DGLA, 20:3, $\mathrm{n}-6$ & $76 \pm 4.9^{*}$ & $8.7 \pm 1.4$ & $15.3 \pm 4.3$ & $125.5 \pm 34.5$ \\
AA, 20:4, $\mathrm{n}-6$ & $20.7 \pm 3.5$ & $64.3 \pm 6.6^{*}$ & $14.3 \pm 3.4$ & $85.1 \pm 19.8$ \\
EPA, 20:5, $\mathrm{n}-3$ & $29.7 \pm 2.2$ & $28.7 \pm 1.9$ & $41.0 \pm 0.8^{*}$ & $16.1 \pm 2.9$ \\
\hline
\end{tabular}

Significant differences between control and treatments are indicated by ${ }^{*} P<0.01$ (statistical analyses carried out on numerical data).

synthesis (Fig. 3) but significantly enhanced $\mathrm{PGE}_{3}$ generation (Table 1). However, a simple shift from synthesis of two- to three-series PGs is just one aspect of a complex situation. Previous studies have shown that supplementation with n-3 PUFAs may actually inhibit two-series PG production (Herrera 2002, Bagga et al. 2003). Simple, competitive inhibition of key elongase and desaturase enzymes in the PUFA elongation pathway for PUFAs derived from the diet is the most obvious explanation. However, Burdge \& Wootton (2002) and Burdge et al. (2002) reported limited ability of humans to elongate and desaturate ALNA, 18:3, n-3, indicating that the type of n-3 PUFAs supplemented in the diet, and hence available to the cells, becomes very significant. There would also be competition between n-3 and n-6 PUFAs for incorporation into phospholipids within cell membranes. For instance, in rat erythrocytes, increased dietary intake of n-3 PUFAs (fish oil supplement) led to significant changes in membrane composition, which resulted in decreased amounts of AA, 20:4, $\mathrm{n}-6$ being stored in membrane phospholipids, which could therefore potentially result in decreased synthesis of two-series PGs (Escudero et al. 1998). Furthermore, during PG synthesis, competition for PTGS enzymes could result in a decrease in two-series PGs with increased n-3 substrate (EPA, 20:5, n-3) availability (Allen \& Harris 2001, Wada et al. 2007). Since EPA, 20:5, n-3 is both a poor substrate for PTGS1 (Smith 2005) and an inhibitor of enzyme activity (Lands 1992), it is unlikely that the three-series PGs are generated as a result of PTGS1 activity. In terms of PTGS2, EPA, 20:5, n-3 is a poor inhibitor of its activity (Wada et al. 2007). Taken together, it would seem more likely that the $n-3$ PUFA-induced decrease in $\mathrm{PGE}_{2}$ observed in this study (Fig. 4) was due to decreased PTGS1 rather than PTGS2 activity.

Increasing inhibitory effects of n-3 PUFAs with increasing chain length have also been reported by other workers (Hwang et al. 1988), with EPA, 20:5, n-3 having a greater inhibitory effect on PG synthesis than ALNA, 18:3, n-3. More recently, similar observations have been reported in human decidual cell cultures where DHA, 22:6, n-3 was found to be more potent than $E P A, 20: 5, n-3$ in inhibiting two-series PG synthesis $\left(\mathrm{PGF}_{2 \alpha}\right.$ and $\mathrm{PGE}_{2}$ ) stimulated by interleukin-1 $\beta$ (Roman et al. 2006). In addition, in the same study, Roman et al. (2006) reported that one of the rate-limiting enzymes associated with the synthesis of $\mathrm{PGE}_{2}$, namely microsomal PGE synthase 1, was also inhibited by DHA, 22:6, $\mathrm{n}$-3. While Roman et al. (2006) reported $\mathrm{PGE}_{2}$ decreases with both EPA, 20:5, n-3 and DHA, 22:6, n-3, we have only observed significant inhibitory effects of n-3 PUFAs, with DHA, 22:6, n-3. Species and tissue differences probably account for the observed variations in the twoseries PGs response between the studies. Another possibility that needs considering is that the concentrations of PGs measured with the $\mathrm{PGE}_{2}$ RIA may actually be a combined value, representing a decrease in twoseries PGs and an increase in three-series PGs. Most studies to date make no attempt to quantify changes in one- and three-series PGs following supplementation with PUFAs. This is a major omission, which we have gone some way towards addressing in the present study where we show that $n-6$ PUFAs do indeed induce increases in two-series PGs (Figs 1 and 2 and Table 1). Conversely, n-3 PUFAs increase three-series PGs, while at the same time, they decrease two-series PGs (Table 1 and Fig. 4). Additional support for the idea that the type and quantity of PGs produced depend upon the type of PUFAs used for supplementation comes from our observations that DGLA, 20:3, n-6 leads to an apparent increase in $\mathrm{PGE}_{1}$ output while decreasing both $\mathrm{PGE}_{2}$ and $\mathrm{PGE}_{3}$ outputs from ovine amnion cells (Table 1).

In summary, we have demonstrated that supplementation in vitro with $\mathrm{n}-6$ PUFAs elicited profound stimulatory effects on PG synthesis in ovine amnion cells. A long-chain n-3 PUFA, DHA, 22:6, n-3, was inhibitory in terms of $\mathrm{PGE}_{2}$ production, whereas shorter chain n-3 PUFAs produced a modest stimulatory effect on $\mathrm{PGE}_{2}$ output. The complexity of the processes involved between dietary intake and tissue specific modulation of PG synthesis makes it very difficult to reach simple conclusions as to the likely effects of changes in dietary PUFA composition on functions in specific cells (Galli et al. 1993). The mechanisms underlying either the increased gestational length or the reduced risk of spontaneous pre-term delivery induced by the high n-3 PUFA diet are poorly 
understood (Wathes et al. 2007). One possible explanation for these effects could be that the n-3 PUFA supplementation induces a change in the pattern of PG synthesis which results in a shift in the production of two- to three-series PGs (Smith 1989, Lands 1992, Abayasekara \& Wathes 1999, Wada et al. 2007). While such changes to the pattern of PG synthesis have long been postulated, little experimental evidence exists to support such a contention. However, if these changes in PG synthesis were to occur, the differences in the biological activity of PGs derived from different families of PUFAs would be able to account for the resulting modifications to the timing of delivery. Hence, the effects reported here do, however, suggest that dietary-induced alterations in the PUFA content of amnion cells have the potential to affect parturition by modulating two-series PG synthesis.

\section{Materials and Methods}

All reagents were from Sigma-Aldrich Chemical Co., unless otherwise stated.

\section{Animals}

Tissues obtained from day 135 pregnant sheep were used for these experiments. The animal experiments were performed under the Animal (Scientific Procedures) Act 1986.

\section{Cell culture}

Sheep were slaughtered on day 135 of gestation (term is 145 days gestation), and the pregnant uterus was removed, washed with $70 \%(\mathrm{v} / \mathrm{v})$ ethanol, and placed in a sterile metal dish in a laminar flow hood. The uterus was opened carefully, and the amnion was manually dissected away from the other tissues. Amnion cells were prepared as previously described by us (Cheng et al. 2003). Briefly, the sheet of amnion tissue was washed three times in Hanks balanced salt solution (HBSS) supplemented with $50 \mathrm{IU} / \mathrm{ml}(\mathrm{v} / \mathrm{v})$ penicillin and streptomycin (ICN Biomedicals, Oxford, UK). All further media used were likewise supplemented with $50 \mathrm{IU} / \mathrm{ml}$ penicillin and streptomycin. The tissue was cut into strips and digested with trypsin/ collagenase $(0.05 \%(\mathrm{v} / \mathrm{v}): 0.05 \%,(\mathrm{w} / \mathrm{v})$, Roche Diagnostics) for $2 \mathrm{~h}$ in a shaking water bath at $37^{\circ} \mathrm{C}$. Amnion cells were then separated from the remains of the digested tissue by filtration through sterile nylon mesh. The resulting suspension of cells was mixed with an equal volume of HBSS containing FCS $(10 \% \mathrm{v} / \mathrm{v}$ FCS). Cells were then centrifuged at $150 \mathrm{~g}$ for 10 min and washed twice in HBSS containing 10\% FCS. Amnion cells were counted using a haemocytometer, and the viability of cell preparation was checked by trypan blue dye exclusion (consistently $>95 \%$ viable). Cells were then plated out in 24-well multi-well plates (Iwaki Scitech DIV, Asahi Techno Glass, Tokyo, Japan) at a density of 500000 cells per well in $2.0 \mathrm{ml}$ of DMEM/F-12 (Gibco Life Technologies) supplemented with $10 \%$ FCS.

\section{Fatty acid supplementation}

All n-6 and n-3 PUFAs used were purchased from Sigma-Aldrich. The n-6 PUFAs were LA (18:2, n-6), $\gamma$-linolenic acid (GLA, 18:3, n-6), DGLA (20:3, n-6) and AA (20:4, n-6). The n-3 PUFAs were ALNA (18:3, n-3), SA (18:4, n-3), EPA (20:5, n-3) and DHA (22:6, $\mathrm{n}-3)$. The fatty acids were initially dissolved in organic solvent (100 $\mathrm{mM}$ in ethanol) and then further diluted in DMEM/F-12 containing $0.1125 \%(\mathrm{w} / \mathrm{v})$ fatty acid-free BSA (to provide a carrier) and $0.1 \%(\mathrm{v} / \mathrm{v})$ ITS media supplement (containing $0.5 \mathrm{mg} / \mathrm{ml}$ insulin, $0.5 \mathrm{mg} / \mathrm{ml}$ transferrin and $0.5 \mu \mathrm{g} / \mathrm{ml}$ selenium). All PUFA treatments were in the concentration range of $0.1-1000 \mu \mathrm{M}$, where the final concentration of the organic solvent was $<0.001 \%$. DMEM/F-12 containing $0.1125 \%$ fatty acid-free BSA and $0.1 \%$ ITS was used as the diluent for all treatments in order to standardise the fatty acid composition of the cell culture medium.

Viability of cells following treatment with PUFAs for $45 \mathrm{~h}$ was determined by the CellTiter 96 Aqueous One Solution Cell Proliferation Assay (MTS) from Promega (Promega Corporation) according to the manufacturer's instructions (Si et al. 2005).

\section{Experimental protocol}

Cells isolated from amnion tissue were cultured to confluence over a period of 6 days (where day $0=$ start of culture period) in DMEM/F-12 containing $10 \%$ FCS at a temperature of $39{ }^{\circ} \mathrm{C}$ in an atmosphere of $5 \%(\mathrm{v} / \mathrm{v}) \mathrm{CO}_{2}$. Medium was changed every 48-72 h. At the start of day 6, culture medium was replaced with DMEM/F-12, supplemented with $0.1125 \%$ fatty acid-free BSA and $0.1 \mathrm{ml} / 100 \mathrm{ml}$ ITS media supplement, for a period of $3 \mathrm{~h}$ to remove any fatty acids present in the FCS (Cheng et al. 2004). Cells were then cultured in the presence of 0,20 or $100 \mu \mathrm{M}$ n-6 PUFAs (LA, 18:2, n-6; GLA, 18:3, n-6; DGLA, 20:3, n-6 or AA, 20:4, n-6) or 0,20 or $100 \mu \mathrm{M}$ n-3 PUFAs (ALNA, 18:3, n-3; SA, 18:4, n-3; EPA, 20:5, n-3 and DHA, 22:6, $\mathrm{n}-3)$ for $45 \mathrm{~h}$, as this time point was shown to be optimal for assessing PG generation following PUFA supplementation in the ovine amnion (Cheng et al. 2003). Four wells of cells were subjected to each different in vitro treatment. This protocol was repeated at least three times using amnion cells from an individual ewe on each occasion. Spent culture medium was stored at $-20{ }^{\circ} \mathrm{C}$ until analysis of PGs by RIA, enzyme immunoassay (EIA) and/or HPLC.

\section{PG RIA}

$\mathrm{PGE}_{2}$ and $\mathrm{PGF}_{2 \alpha}$ in the spent medium were quantified by RIA as validated and described previously for samples of ovine origin (Cheng et al. 2003). The tritiated tracers of $\mathrm{PGE}_{2}([5,6,8,11$, $\left.\left.12,14,15(\mathrm{n})-{ }^{3} \mathrm{H}\right] \mathrm{PGE}_{2}\right)$ and $\mathrm{PGF}_{2 \alpha}([5,6,8,11,12,14,15$ (n)- $\left.{ }^{3} \mathrm{H}\right] \mathrm{PGF}_{2 \alpha}$ ) were obtained from Amersham International, and the PG standards were obtained from Sigma-Aldrich. The PG antisera (anti-PGE 2 and anti-PGF ${ }_{2 \alpha}$ ) were a kind gift from Prof. N L Poyser (University of Edinburgh, Edinburgh, UK; Poyser 1987). Respective cross reactivities of PGs have been reported previously (Cheng et al. 2005a, 2005b) and were estimated to be as follows in the present study: anti-PGE $2,23 \%$ with $\mathrm{PGE}_{1}, 100 \%$ with $\mathrm{PGE}_{2}$ and $15 \%$ with $\mathrm{PGE}_{3}$; anti-PGF $\mathrm{PG}_{2 \alpha}$ $25 \%$ with $\mathrm{PGF}_{1 \alpha}, 100 \%$ with $\mathrm{PGF}_{2 \alpha}$ and $18 \%$ with $\mathrm{PGF}_{3 \alpha}$. 


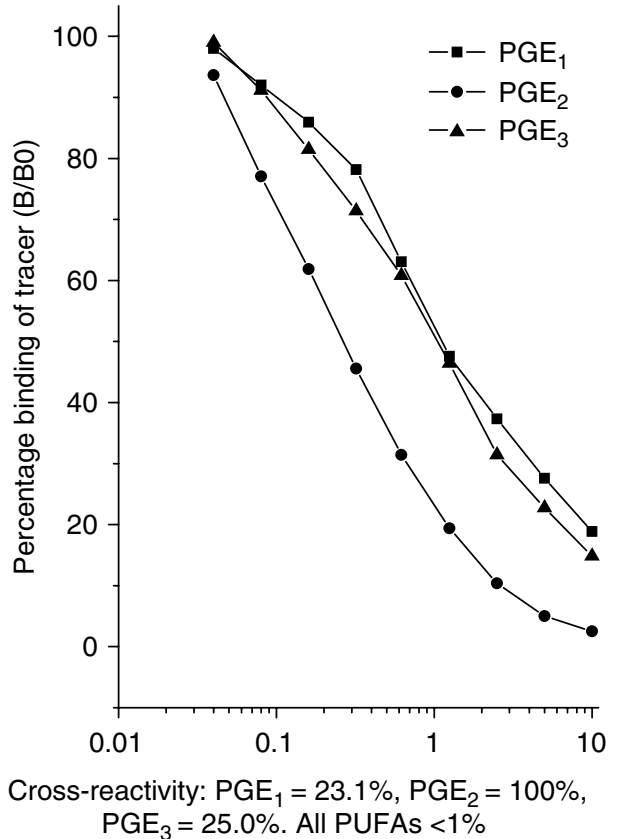

Figure 5 Specificity of the $\mathrm{PGE}_{2}$ antibody for PGE isomers. RIA was carried out using anti-PGE $\mathrm{P}_{2}$ and $\left[{ }^{3} \mathrm{H}\right]-\mathrm{PGE}_{2}$ with standards against $\mathrm{PGE}_{1}$, $\mathrm{PGE}_{2}$ and $\mathrm{PGE}_{3}$ as described in the Materials and Methods section.

The RIAs for $\mathrm{PGE}_{1}$ and $\mathrm{PGE}_{3}$ were carried out using the anti-PGE $E_{2}$ antiserum and the ${ }^{3} \mathrm{H}-\mathrm{PGE}_{2}$ tracer but with authentic $\mathrm{PGE}_{1}$ and $\mathrm{PGE}_{3}$ standards (Fig. 5) as described for the assay of $\mathrm{PGF}_{1 \alpha}$ and $\mathrm{PGF}_{3 \alpha}$ (Cheng et al. 2005a). The samples were diluted appropriately in $0.05 \mathrm{M}$ Tris buffer containing $0.1 \%$ $(\mathrm{w} / \mathrm{v})$ gelatin and $0.01 \%(\mathrm{w} / \mathrm{v})$ sodium azide and assayed as previously described (Cheng et al. 2003). The limit of detection was 1 pg/tube for $\mathrm{PGF}_{2 \alpha}, 2 \mathrm{pg} /$ tube for $\mathrm{PGE}_{2}$ and $100 \mathrm{pg} / \mathrm{tube}$ for $\mathrm{PGE}_{1}$ and $\mathrm{PGE}_{3}$. The cross reactivity of anti-PGE $\mathrm{PG}_{2}$ with $\mathrm{PGF}_{2 \alpha}$ and anti-PGF $2 \alpha$ with $\mathrm{PGE}_{2}$ was $<0.8 \%$.

\section{HPLC}

PGE isomers were separated using HPLC methodology as described previously for the separation of PGF isomers (Cheng et al. 2005a) where the system details were as follows: a Beckman C18 Ultrasphere $5 \mu$ ODS2 column $(4.6 \times 25 \mathrm{~cm})$ with a compatible $\mathrm{C} 18$ guard column and a solvent system of $17 \mathrm{mM}$ phosphoric acid:acetonitrile $(74: 26 \mathrm{v} / \mathrm{v})$ was used in conjunction with a Beckman Gold HPLC system (Brea, CA 92622-9855, USA) equipped with a UV detector (Beckman Gold 166), a fraction collector (Beckman SC100), a gradient pump (Beckman 125 pump) and a Beckman Gold Nouveau data acquisition system (V1.1.). In order to determine the retention time of $\mathrm{PGE}$ isomers, $\mathrm{PGE}_{1}, \mathrm{PGE}_{2}$ and $\mathrm{PGE}_{3}$ standards $(20 \mu \mathrm{l}$ of $50 \mu \mathrm{g} / \mathrm{ml})$ in acetonitrile were injected onto the column, where the flow rate was $1 \mathrm{ml} / \mathrm{min}$ and the wavelength of detection was $196 \mathrm{~nm}$. In this system, the average retention times of the three PGE isomers were as follows: $\mathrm{PGE}_{3}$, $12.5 \mathrm{~min}$; $\mathrm{PGE}_{2}, 19 \mathrm{~min}$; and $\mathrm{PGE}_{1}, 22 \mathrm{~min}$.

Samples of cell culture medium from cultures that had been supplemented with the same in vitro treatments were pooled, and various isoforms were separated by HPLC (Cheng et al. 2005a). The three isoforms were identified by comparison to commercial standards of $\mathrm{PGE}_{1}, \mathrm{PGE}_{2}$ and $\mathrm{PGE}_{3}$. Fractions containing individual peaks were then pooled and freeze-dried, before being reconstituted in RIA buffer. Concentrations of the relevant PGE isoforms were derived from standard curves plotted for individual PGE isoforms (Fig. 5).

\section{Enzyme immunoassay}

$\mathrm{PGE}_{1}$ EIA assay kits were obtained from Assay Designs, Inc., Ann Arbor, MI, USA. Cross reactivities of the alternative isoforms of PGE with these assay kits were $100 \%$ for $\mathrm{PGE}_{1}$, $6.5 \%$ for $P G E_{2}$ and $2.22 \%$ for $\mathrm{PGE}_{3}$. This was confirmed by testing a range of concentrations of $\mathrm{PGE}_{2}$ and $\mathrm{PGE}_{3}$ alongside the standards of $\mathrm{PGE}_{1}$ in pre-assays.

$\mathrm{PGE}_{1}$ levels were estimated in a number of samples of spent cell culture medium. Samples were diluted appropriately prior to assay according to the manufacturer's instructions where the threshold for detection was $5.5 \mathrm{pg} / \mathrm{ml} \mathrm{PGE}_{1}$.

\section{Statistical analysis}

Results are quoted as the mean \pm s.E.M. (ng/ml per $45 \mathrm{~h}$ ) of $\mathrm{PGE}_{2}$ concentrations in culture medium unless otherwise stated. The $n$ value quoted refers to the number of sheep and equals three unless otherwise stated. In vitro treatments were replicated in four wells of cells in each experiment. Each experiment was repeated at least three times with cells isolated from an individual sheep on each occasion. PG data were analysed by a general linear model ANOVA programme using a repeated-measures design (SAS Inc., Cary, NC, USA) unless otherwise stated. The Bonferroni test was used to make post hoc comparisons. A significance $(P)$ value of $<0.05$ was taken to indicate a significant difference between treatments.

\section{Declaration of interest}

The authors declare that they have no conflict of interest that could be perceived as prejudicing the impartiality of the research reported.

\section{Funding}

This work was funded by the BBSRC (Grant Ref: 48 D11998), and S E Kirkup was supported by a BBSRC committee studentship.

\section{Acknowledgements}

We are grateful to the animal technicians of the Royal Veterinary College for care of the ewes and to Prof. Norman Poyser for the gift of the prostaglandin antibodies. 


\section{References}

Abayasekara DRE \& Wathes DC 1999 Effects of altering dietary fatty acid composition on prostaglandin synthesis and fertility. Prostaglandins, Leukotrienes, and Essential Fatty Acids 61 275-287. (doi:10.1054/plef. 1999.0101)

Allen KGD \& Harris MA 2001 The role of n-3 fatty acids in gestation and parturition. Experimental Biology and Medicine 226 498-506.

Arntzen KJ, Brekke OL, Vatten L \& Austgulen R 1998 Reduced production of $\mathrm{PGE}_{2}$ and $\mathrm{PGF}_{2 \alpha}$ from decidual cell cultures supplemented with $\mathrm{n}-3$ polyunsaturated fatty acids. Prostaglandins \& Other Lipid Mediators 56 183-195. (doi:10.1016/S0090-6980(98)00048-3)

Auletta FJ \& Flint APF 1988 Mechanisms controlling corpus luteum function in sheep, cows, nonhuman primates, and women especially in relation to the time of luteolysis. Endocrine Reviews 9 88-105. (doi:10. 1210/edrv-9-1-88)

Bagga D, Wang L, Farias-Eisner R, Glaspy JA \& Reddy ST 2003 Differential effects of prostaglandin derived from $\omega-6$ and $\omega-3$ polyunsaturated fatty acids on COX-2 expression and IL-6 secretion. PNAS 100 1751-1756. (doi:10.1073/pnas.0334211100)

Baguma-Nibasheka M, Brenna JT \& Nathaniels PW 1999 Delay of preterm delivery in sheep by omega-3 long-chain polyunsaturates. Biology of Reproduction 60 698-702. (doi:10.1095/biolreprod60.3.698)

Belch JJF \& Hill A 2000 Evening primrose oil and borage oil in rheumatologic conditions. American Journal of Clinical Nutrition 71 (Supplement) 352S-356S.

Bendich A 2000 The potential for dietary supplements to reduce premenstrual syndrome (PMS) symptoms. Journal of the American College of Nutrition 19 3-12.

Bennet PR, Slater D, Sullivan M, Elder MG \& Moore GE 1993 Changes in amniotic arachidonic acid metabolism associated with increased cylcooxygenase gene expression. British Journal of Obstetrics and Gynaecology 100 1037-1042. (doi:10.1111/j.1471-0528.1993.tb15143.x)

Burdge GC \& Wootton SA 2002 Conversion of $\alpha$-linolenic acid to eicosapentaenoic, docosapentaenoic and docosahexaenoic acids in young women. British Journal of Nutrition 88 411-420. (doi:10.1079/ BJN2002689)

Burdge GC, Jones AE \& Wootton SA 2002 Eicosapentaenoic and docosapentaenoic acids are the principal products of $\alpha$-linolenic metabolism in young men. British Journal of Nutrition 88 355-363. (doi:10.1079/BJN2002662)

Carvalho CB, Yeik BS \& Murdoch WJ 1989 Significance of follicular cyclooxygenase and lipoxygenase pathways of metabolism of arachidonate in sheep. Prostaglandins 37 553-558. (doi:10.1016/00906980(89)90070-1)

Challis JRG, Matthews SG, Gibb W \& Lye SJ 2000 Endocrine and paracrine regulation of birth at term and preterm. Endocrine Reviews 21 514-550. (doi:10.1210/er.21.5.514)

Challis JRG, Sloboda DM, Alfaidy N, Lye SJ, Gibb W, Patel FA, Whittlee WL \& Newnham JP 2002 Prostaglandins and mechanisms of preterm birth. Reproduction 124 1-17. (doi:10.1530/rep.0.1240001)

Cheng Z, Elmes M, Abayasekara DRE \& Wathes DC 2003 Effects of conjugated linoleic acid on prostaglandins produced by cells isolated from maternal intercotyledonary endometrium, fetal allantochorion and amnion in late pregnant ewes. Biochimica et Biophysica Acta 1633 170-178. (doi:10.1016/S1388-1981(03)00123-9)

Cheng Z, Elmes M, Kirkup SE, Abayasekara DRE \& Wathes DC 2004 Alteration of prostaglandin production and agonist responsiveness by n-6 polyunsaturated fatty acids in endometrial cells from late gestation ewes. Journal of Endocrinology 182 249-256. (doi:10.1677/joe.0. 1820249)

Cheng Z, Abayasekara DRE \& Wathes DC 2005a The effect of supplementation with n-6 polyunsaturated fatty acids on 1-, 2- and 3-series prostaglandin $\mathrm{F}$ production by ovine uterine epithelial cells. Biochimica et Biophysica Acta 1736 128-135. (doi:10.1016/j.bbalip. 2005.08.007)

Cheng Z, Elmes M, Kirkup SE, Chin EC, Abayasekara DRE \& Wathes DC $2005 b$ The effect of a diet supplemented with the n-6 polyunsaturated fatty acid linolenic acid on prostaglandin production in early- and late-pregnant ewes. Journal of Endocrinology 184 165-178. (doi:10. 1677/joe.1.05910)
Coleman RA, Smith WL \& Narumiya S 1994 International union of pharmacology classification of prostanoid receptors: properties, distribution and structure of the receptors and their subtypes. Pharmacological Reviews 46 205-229.

Department of Health 1994 Nutritional Aspects of Cardiovascular Disease. Report of the Cardiovascular Review Group Committee on Medical Aspects Food Policy. Report on Health and Social Subjects (London). HMSO 46 1-186.

Elmes M, Green LR, Poore K, Newman J, Burrage D, Abayasekara DRE, Cheng Z, Hanson MA \& Wathes DC 2005 Raised dietary n-6 intake increases prostaglandin production during labour in the ewe. Journal of Physiology 562 583-592. (doi:10.1113/jphysiol.2004.071969)

Escudero A, Montilla JC, Garcia JM, Snachez-Quevedo MC, Periago JL, Hortelano P \& Suarez MD 1998 Effect of dietary (n-9), (n-6) and (n-3) fatty acids on membrane lipid composition and morphology of rat erythrocytes. Biochimica et Biophysica Acta 1394 65-73.

Furuyashiki T \& Narumiya S 2009 Roles of prostaglandin E receptors in stress. Current Opinion in Pharmacology 9 31-38. (doi:10.1016/j.coph. 2008.12.010)

Galli C, Marangoni F \& Galella G 1993 Modulation of lipid derived mediators by polyunsaturated fatty acids. Prostaglandins, Leukotrienes, and Essential Fatty Acids 48 51-55. (doi:10.1016/09523278(93)90009-L)

Goldberg RJ \& Katz J 2007 A meta-analysis of the analgesic effects of omega-3 polyunsaturated fatty acid supplementation for inflammatory joint pain. Pain 129 210-223. (doi:10.1016/j.pain.2007.01.020)

Grieves SA \& Liggins GC 1976 Phospholipase activity in human and ovine uterine tissues. Prostaglandins 12 229-241. (doi:10.1016/00906980(76)90118-0)

Gyomorey S, Lye SJ, Gibb W \& Challis JR 2000 Fetal-to-maternal progression of prostaglandin $\mathrm{H}(2)$ synthase-2 expression in ovine intrauterine tissues during the course of labor. Biology of Reproduction 62 797-805. (doi:10.1095/biolreprod62.3.797)

Herrera E 2002 Implications of dietary fatty acids during pregnancy on placental fetal and postnatal development - a review. Placenta 23 (Supplement A) S9-S19. (doi:10.1053/plac.2002.0771)

Horrobin DF \& Manku MS 1990 Clinical biochemistry of essential fatty acids. In Omega-6 Essential Fatty Acids, pp 21-53. Ed. DF Horrobin. New York: Wiley-Liss.

Hwang DH, Bodreau M \& Chanmugam P 1988 Dietary linolenic and longer-chain $\mathrm{n}-3$ fatty acids: comparison of effects on arachidonic acid metabolism in rats. Journal of Nutrition $118427-437$.

Jabbour HN, Sales KJ, Catalano RD \& Norman JE 2009 Inflammatory pathways in female reproductive health and disease. Reproduction 138 903-919. (doi:10.1530/REP-09-0247)

Kobzar G, Mardia V, Jarving I, Lohmus M, Vahemets A, Samel N \& Lille U 1993 Comparison of the inhibitory effects of E-prostaglandins in human and rabbit platelet-rich plasma and washed platelets. Comparative Biochemistry and Physiology 106 489-494. (doi:10.1016/0742-8413 (93)90168-K)

Lands WEM 1992 Biochemistry and physiology of n-3 fatty acids. FASEB Journal 6 2530-2536.

Ma XH, Wu XW, Brenna JT \& Nathanielsz PW 2000 Maternal intravenous administration of long chain $n-3$ polyunsaturates to the pregnant ewe in late gestation results in specific inhibition of prostaglandin $\mathrm{H}$ synthase (PGHS) 2, but not PGHS1 and oxytocin receptor mRNA in myometrium during betamethasone-induced labor. Journal of the Society for Gynecologic Investigation 7 233-237. (doi:10.1016/S1071-5576(00) 00063-0)

McCracken JA, Glew ME \& Scaramuzzi RJ 1970 Corpus luteum regression induced by prostaglandin F2-alpha. Prostaglandins 30 544-546.

McLaren WJ, Young IR, Wong MH \& Rice GE 1996 Expression of prostaglandin $\mathrm{G} / \mathrm{H}$ synthase- 1 and -2 in ovine amnion and placenta following glucocorticoid-induced labour onset. Journal of Endocrinology 151 125-135. (doi:10.1677/joe.0.1510125)

McLaren WJ, Young IR \& Rice GE 2000 Localisation and temporal changes in prostaglandin $\mathrm{G} / \mathrm{H}$ synthase- 1 and -2 in ovine intrauterine tissues in relation to glucocorticoid-induced and spontaneous labour. Journal of Endocrinology 165 399-410. (doi:10.1677/joe.0.1650399)

Mitchell BF \& Taggart MJ 2009 Are animal models relevant to key aspects of human parturition? American Journal of Physiology 297 R525-R545. (doi:10.1152/ajpregu.00153.2009) 
Myatt L \& Sun K 2010 Role of fetal membranes in signaling of fetal maturation and parturition. International Journal of Developmental Biology 54 545-553. (doi:10.1387/ijdb.082771lm)

Okazaki T, Casey ML, Okita JR, MacDonald PC \& Johnston JM 1981 Initiation of human parturition. X11. Biosynthesis and metabolism of prostaglandins in human fetal membranes and uterine deciduas. American Journal of Obstetrics and Gynecology 139 373-380.

Okita JR, MacDonald PC \& Johnston JM 1982 Initiation of human parturition. American Journal of Obstetrics and Gynecology 142 432-435.

Olsen SF \& Secher NJ 1990 A possible preventative effect of low-dose fish oil on early delivery and pre-eclampsia: indications from a 50-year-old controlled trial. British Journal of Nutrition 64 599-609. (doi:10.1079/ BJN19900063)

Olsen SF, Hansen HS, Sommer S, Jensen B, Sorensen TIA, Secher NJ \& Zachariassen $\mathbf{P} 1991$ Gestational age in relation to marine $n-3$ fatty acids n maternal erythrocytes: a study of women in the Faroe Islands and Denmark. American Journal of Obstetrics and Gynecology 164 1203-1209.

Olsen SF, Osterdal ML, Salvig JD, Kesmodel U, Henriksen TB, Hedegaard M \& Secher NJ 2006 Duration of pregnancy in relation to seafood intake during early and mid pregnancy:prospective cohort. European Journal of Epidemiology 21 749-758. (doi:10.1007/s10654006-9053-6)

Olsen SF, Osterdal ML, Weber T, Tabor A \& Secher NJ 2007 Duration of pregnancy in relation to fish oil supplementation and habitual fish intake: a randomized clinical trial with fish oil. European Journal of Clinical Nutrition 61 976-985. (doi:10.1038/sj.ejcn.1602609)

Olson DM 2003 The role of prostaglandins in the initiation of parturition. Best Practice \& Research. Clinical Obstetrics \& Gynaecology 17 717-730. (doi:10.1016/S1521-6934(03)00069-5)

Olson DM, Lye SJ, Skinner K \& Challis JR 1985 Prostanoid concentrations in maternal/fetal plasma and amniotic fluid and intrauterine tissue prostanoid output in relation to myometrial contractility during the onset of adrenocorticotropin-induced preterm labor in sheep. Endocrinology 116 389-397. (doi:10.1210/endo-116-1-389)

Olson DM, Lye SJ \& Challis JR 1986 Prostaglandin concentrations in ovine maternal and fetal tissues at late gestation. Pediatric Research 20 83-86. (doi:10.1203/00006450-198601000-00023)

Palliser HK, Hirst JJ, Rice GE, Ooi GT, Dellios NL, Escalona RM \& Young IR 2006 Labor-associated regulation of prostaglandin E and F synthesis and action in the ovine amnion and cervix. Journal of the Society for Gynecologic Investigation 13 19-24. (doi:10.1016/j.jsgi.2005.09.009)

Pavan B, Fiorini S, Ferretti ME, Vesce F \& Biondi C 2003 WISH cells as a model for the in vitro study of amnion pathophysiology. Current Drug Targets. Immune, Endocrine and Metabolic Disorders 3 83-92. (doi:10. 2174/1568008033340324)

Poyser NL 1987 Effects of various factors on prostaglandin synthesis by the guinea-pig uterus. Journal of Reproduction and Fertility 81 269-276. (doi:10.1530/jrf.0.0810269)

Remans PH, Sont JK, Wagenaar LW, Wouters-Wesseling W, Zuiderduin WM, Jongma A, Breedveld FC \& Vanlaar JM 2004 Nutrient supplementation with polyunsaturated fatty acids and micronutrients in rheumatoid arthritis: clinical and biochemical effects. European Journal of Clinical Nutrition 58 830-845. (doi:10.1038/sj.ejcn.1601883)

Rice GE, Wong MH \& Thorburn GD 1990 Prostaglandin G/H synthase activity in ovine cotyledons: a gestational profile. Eicosanoids 3 231-236.

Rice GE, Freed KA, Aitken MA \& Jacobs RA 1995 Gestational- and labor associated changes in relative abundance of prostaglandin $\mathrm{G} / \mathrm{H}$ synthase- 1 and -2 mRNA in ovine placenta. Journal of Molecular Endocrinology 14 237-245. (doi:10.1677/jme.0.0140237)

Roman AS, Schreher J, Mackenzie AP \& Nathanielsz PW 2006 Omega-3 fatty acids and decidual cell prostaglandin production in response to the inflammatory cytokine IL-1 $\beta$. American Journal of Obstetrics and Gynecology 195 1693-1699. (doi:10.1016/j.ajog.2006.04.009)

Sawdy RJ, Slater DM, Dennes WJB, Sulllivan MHF \& Bennet PR 2000 The roles of cycooxygenases types one and two in prostaglandin synthesis in human fetal membranes at term. Placenta 21 54-57. (doi:10.1053/plac.1999.0438)
Shand JH \& Noble RC 1981 The metabolism of $18: 0$ and 18:2(n-6) by the ovine placenta at 120 and 150 days of gestation. Lipids 16 68-71. (doi:10.1007/BF02534924)

Sheldrick EL, Derecka K, Marshal E, Chin EC, Hodges L, Wathes DC, Abayasekara DRE \& Flint APF 2007 Peroxisome-proliferator-activated receptors and the control of levels of prostaglandin-endoperoxide synthase 2 by arachidonic acid. Biochemical Journal 406 175-183. (doi:10.1042/B)20070089)

Si X, McManus BM, Zhang J, Yuan J, Cheung C, Esfandiarei M, Suarez A, Morgan A \& Luo H 2005 Pyrrolidine dithiocarbamate reduces coxsacjievirus B3 replication through inhibition of the ubiquitinproteosome pathway. Journal of Virology 79 8014-8023. (doi:10.1128/ JVI.79.13.8014-8023.2005)

Slater D, Dennes W, Sawdy R, Allport V \& Bennet P 1999 Expression of cyclo-oxygenases types-1 and -2 in human fetal membranes throughout pregnancy. Journal of Molecular Endocrinology 22 125-130. (doi:10. 1677/jme.0.0220125)

Smith WL 1989 The eicosanoids and their biochemical mechanisms of action. Biochemical Journal 259 313-324.

Smith WL 1992 Prostanoid biosynthesis and mechanisms of action. American Journal of Physiology 263 F181-F191.

Smith WL 2005 Cyclooxygenases, peroxide tone and the allure of fish oil. Current Opinion in Cell Biology 17 174-182. (doi:10.1016/j.ceb.2005. 02.005)

Smith WL, Garavito RM \& DeWitt DL 2000 Cyclooxygenases: structural, cellular and molecular biology. Annual Review of Biochemistry 69 145-182. (doi:10.1146/annurev.biochem.69.1.145)

Sugimoto Y \& Narumiya S 2007 Prostaglandin E receptors. Journal of Biological Chemistry 282 11613-11617. (doi:10.1074/jbc.R600038200)

Szajewska H, Horvath A \& Koletzko B 2006 Effect of n-3 long chain polyunsaturated fatty acid supplementation of women with low-risk pregnancies on pregnancy outcomes and growth measures at birth: a meta analysis of randomized controlled trials. American Journal of Clinical Nutrition 83 1337-1344.

Tapiero H, Ba GN, Couvreur P \& Tew KD 2002 Polyunsaturated fatty acids (PUFA) and eicosanoids in human health and pathologies. Biomedicine \& Pharmacotherapy 56 215-223. (doi:10.1016/S0753-3322(02)00193-2)

Thorburn GD 1991 The placenta, prostaglandins and parturition: a review. Reproduction, Fertility, and Development 3 277-294. (doi:10.1071/ RD9910277)

Uozumi N, Kume K, Nagase T, Nakatani N, Ishii S, Tashiro F, Komagata $Y$, Maki K, Ikuta K, Ouchi Y et al. 1997 Role of cytosolic phospholipase $A_{2}$ in allergic response and parturition. Nature 390 618-622. (doi:10.1038/ 37622)

Wada M, deLong CJ, Hong YH, Rieke CJ, Song I, Sidhu RS, Yuan C, Warnock M, Schmaier AH, Yokoyama C et al. 2007 Enzymes and receptors of prostaglandin pathways with arachidonic acid-derived versus eicosapentenoic acid-derived substrates and products. Journal of Biological Chemistry 282 22254-22266. (doi:10.1074/jbc.M70316 9200)

Wathes DC, Abayasekara DRE \& Aitken RJ 2007 Polyunsaturated fatty acids in male and female reproduction. Biology of Reproduction 77 190-201. (doi:10.1095/biolreprod.107.060558)

Weems CW, Weems YS \& Randel RD 2006 Prostaglandins and reproduction in female farm animals. Veterinary Journal 171 206-228. (doi:10.1016/j.tvjl.2004.11.014)

Welsh T, Mitchell CM, Walters WA, Mesiano S \& Zakar T 2005 Prostaglandin $\mathrm{H} 2$ synthase- 1 and -2 expression in guinea pig gestational tissues during late pregnancy and parturition. Journal of Physiology 569 903-912. (doi:10.1113/jphysiol.2005.098129)

Whittle WL, Holloway AC, Lye SJ, Gibb W \& Challis JR 2000 Prostaglandin production at the onset of ovine parturition is regulated by both estrogenindependent and estrogen-dependent pathways. Endocrinology 141 3783-3791. (doi:10.1210/en.141.10.3783)

Received 28 December 2009

First decision 8 February 2010

Revised manuscript received 27 August 2010

Accepted 7 September 2010 